\title{
Extrovert Personality Type and Prolonged Second Stage of Labor
}

\section{Hubungan Tipe Kepribadian Ekstrovert dan Persalinan Kala II Lama}

\author{
Yuni Kusmiyati*, Chandra Tyas Nurfitria**, Suherni*, Heni Puji Wahyuningsih*
}

\author{
*Department of Midwifery, Yogyakarta Health Polytechnic Ministry of Health, Yogyakarta, Indonesia, \\ **Department of Midwifery, Vocational School, Gadjah Mada University, Yogyakarta, Indonesia
}

\begin{abstract}
Personality can affect individual's response that implicate in duration of labor. Previous studies showed relationship between personality and duration of labor. People with extrovert personality type (type A) tend to be more susceptible to stress than introvert personality type (type B). This study aimed to determine correlation between extrovert personality type and prolonged second stage of labor by considering external variables such as maternal education, economy, age and parity. A case control study was conducted on 156 parturient women who fulfilled the inclusion criteria of study, such as in Yogyakarta in 2015. Case samples were 52 women with prolonged second stage of labor and control were 104 women with normal second stage of labor. Purposive sampling method was used. Personality type assessment used type A/B questionnaire of Jenkins Activity Survey. Data analysis used logistic regression. Results showed that $80.8 \%$ prolonged second stage of labor occurred in type A mothers and $19.2 \%$ in type B mothers. Extrovert personality type had a significant correlation with prolonged second stage of labor ( $p$ value $<0.05)$. Type A mothers have a risk 8.2 times $(95 \% \mathrm{Cl}: 3.7-18.4)$ of prolonged second stage of labor than type $B$ mothers after be controlled with economic status, parity, maternal education and age.
\end{abstract}

Keywords: Childbirth process, extrovert personality type, delivery

\begin{abstract}
Abstrak
Kepribadian dapat memengaruhi respons individu yang dapat berdampak pada proses persalinan lama. Penelitian sebelumnya menunjukkan adanya hubungan kepribadian dengan waktu persalinan. Tipe kepribadian ekstrover (tipe A) cenderung lebih rentan terhadap stres dibandingkan orang dengan tipe kepribadian introvert (tipe B). Penelitian ini bertujuan untuk mengetahui hubungan tipe kepribadian ekstrover dan variabel luar (pendidikan, ekonomi, usia ibu dan paritas) dengan persalinan kala II lama. Studi kasus kontrol dilakukan pada 156 ibu bersalin yang memenuhi kriteria inklusi pada tahun 2015 di Yogyakarta. Sampel kasus adalah 52 ibu dengan persalinan kala II lama dan kontrol adalah 104 ibu dengan persalinan kala II normal. Penelitian ini menggunakan metode purposive sampling. Tipe kepribadian dinilai menggunakan kuesioner tipe A/B Jenkins Activity Survey. Analisis data menggunakan regresi logistik. Hasil penelitian menunjukkan $80,8 \%$ kala II persalinan lama terjadi pada ibu dengan kepribadian tipe A dan 19,2\% pada ibu dengan kepribadian tipe B. Tipe kepribadian ekstrover memiliki hubungan signifikan terhadap kala II persalinan lama (nilai p < 0,05). Ibu dengan kepribadian tipe A berisiko 8.2 kali (95\% Cl: 3,7-18,4) mengalami persalinan kala II lama dibandingkan ibu dengan kepribadian tipe B setelah dikontrol variabel status ekonomi, paritas, pendidikan dan usia ibu.
\end{abstract} Kata kunci: Proses Persalinan, tipe kepribadian ekstrover, persalinan

How to Cite: Kusmiyati Y, Nurfitria CT, Suherni, Wahyuningsih HP. Extrovert personality type and prolonged second stage of labor. Kesmas: National Public Health Journal. 2017; 11 (4): 173-177. (doi:10.21109/kesmas.v11i4. 1206)
Correspondence: Yuni Kusmiyati, Department of Midwifery Health Polytechnic of Health Ministry, Mangkuduyan MJ III/304 street 55143, Yogyakarta, Phone: +62274-374331,e-mail:yuni_kusmiyati@yahoo.co.id

Received: October $4^{\text {th }} 2016$

Revised: February $2^{\text {nd }} 2017$

Accepted: April 3rd 2017 


\section{Introduction}

The second stage of labor starts when the cervix is fully retracted and ends with birth. ${ }^{1}$ Prolonged second stage of labor occurs when delivery of the fetus takes more than two hours in primiparous and one hour in multiparous. ${ }^{2-4}$ The incidence of prolonged labor in Indonesia is about $5 \% .{ }^{5}$ Prolonged second stage of labor may lead to maternal and fetal death. Prolonged second stage of labor is the fifth cause of maternal mortality after hemorrhage, eclampsia, infections and complications of childbirth. 2,4,6,7

The success of the delivery process is strongly influenced by the synchronous interaction effort which involves strength and power, passage, passenger, and psyche. ${ }^{8}$ Labor pain that cannot be adapted by the mother will increase feelings of anxiety in the mother. Anxiety can cause a long labor. ${ }^{9}$ One of the psychological aspects which is innately embedded in an incline to be permanent is personality. Everyone has a different personality because it is influenced by genotype, an inherited genetic trait. Personality is also influenced by phenotype, the characteristics of an individual resulting from the interaction with the environment. A personality type is relatively permanent and does not easily or significantly change. A personality type is a psychological characteristic which inclines to be unaltered for long periods of time. 10

One system of personality categorization posits two types, extrovert and introvert. Individuals with introvert personality (type B) tend to have a calm attitude and more patience, so they are able to enjoy life more. On the other hand, individuals with extrovert personality (type A) have a tendency to be easily overcome by frustration and stress. Extrovert personality trait (type A) tend to be more susceptible to stress than people with introvert personality type (type B).11-14 Personality type can be assessed by type A/B questionnaire of Jenkins Activity Survey. Questionnaires written in Indonesian have been validated. The questionnaires' reliability has also been tested by using a Cronbach alpha of 0.86. ${ }^{15}$

The stress and anxiety that a woman experiences during delivery process results increased sympathetic tone of muscles. This condition also triggers adrenalin leading to constriction of blood vessels. As a result, it reduces the flow of blood which carries oxygen to the uterine. Eventually, it leads to failure in the contractions and prolonged delivery time. Stress during labor can result from personality. ${ }^{16,17}$

A mother's personality type is one of the important factors which affect her psychological condition and labor process. It needs more attention from the early stages of pregnancy to provide mental support and effective stress management. Comprehending the mother's personality type leads to more focused recognition process and health education to prevent interference/psychological problems which might occur during labor process. ${ }^{16}$

Recently, numerous studies on factors influencing prolonged labor have been conducted. However, the study of the relationship between personality and prolonged labor has not been done yet. This study aimed to determine correlation between extrovert personality type and prolonged second stage of labor after consideration of external variables (maternal education, economy, age and parity).

\section{Method}

This study used a case-control design. Samples were women who gave birth in Wates Hospital Yogyakarta, with inclusion criteria including the birth weight of child $<4000$ gram, participants did not have complications and comorbidities and history of mental illness. Subjects were excluded if their address was not found, they were not willing to be sample and not able to communicate. The study was conducted in January to October 2015 with purposive sampling. The case samples were women with prolonged second stage of labor (second stage of labor more than two hours for multiparous and one hour for primiparous) and control women with normal second stage of labor (second stage of labor $\leq 2$ hours for multiparous and $\leq 1$ hour for primiparous). ${ }^{2-4}$ The data were based on diagnosis recorded in the medical record. Both groups were then searched one by one according to the address on medical record.

The following step was to assess their personality by using a personality type A/B questionnaire of Jenkins Activity Survey. This questionnaire consisted of 20 questions in which each question received a different score. A high score in the questionnaire indicated that the subject was an extrovert personality, and a low score represented an introvert personality. Personality was categorized into extrovert type (type A) if the score of questionnaire reached 201-380. Personality was categorized into introvert type (type B) if the score of questionnaire was 40$200 .{ }^{15}$ The questionnaire was translated into Indonesian language. Further, it was validated and underwent a reliability test with Cronbach alpha value of 0.86 . Personality type was assessed. In order to ensure the accuracy and comparability of the data collection, a workshop was conducted before the commencement of fieldwork. During the data collection process, the respondents were given a full explanation of the study purpose before being invited to participate. Then after they signed the informed consent, a face-to-face interview was conducted. As a quality control, the supervisors checked the completeness of the questionnaire at the end of each day. If information was missing, the interviewer went back on the same or the following day to obtain the missing information.

Covariates were investigated. A possible confounder 
was maternal age. It would be riskier if the mother was younger than 20 years old or older than 35 years old. Moreover, parity is included into risky category if primiparas have parity 1 or parity $>4$, while the parity $2-4$ is included into less risky category. A power test determined that each group should contain a minimum of 52 as calculated by using a case control study according to Kelsey, ${ }^{18}$ using $\alpha=0.05$, power $=80$. For statistical analysis, the bivariate analysis used chi square tests, and the multivariate analysis used logistic regression. The $\mathrm{p}$ value of the likelihood ratio to the chi square was used as a guide to the model's goodness of fit. All $p$ values were two-tailed and statistical significant level was set as less than 0.05 .

\section{Results}

There were 656 births in Wates Hospital Yogyakarta in 2015, which met the inclusion criteria. Of these, there were 69 cases (prolonged second stage of labor) and 587 controls (normal second stage of labor). As many as 69 subjects from case group were traced by finding their address obtained from their medical record. After finding the study subjects, then their personalities were assessed. Of these 69 subjects, five subjects could not be found. Thus, the case group contained 52 subjects. Subjects for the control group were 104. Therefore, the total of subjects who participated in the study was 156 subjects (52 for case group and 104 for control group).

Table 1 presents the comparability of the study subjects between case and control groups based on their educational background, parity, age, economy. Table 1 shows no significant differences in the characteristics of educa- tion, economic level, age and parity between the case and control. This illustrates that these two groups had comparable characteristics. Correlation between extrovert personality type and duration of labor process was analyzed by chi square.

Table 2 performs the correlation between extrovert personality type and prolonged second stage of labor. Type A mothers had higher risk 8.2 times with $95 \%$ confidence interval $(\mathrm{CI})$ 3.72-18.4 than type B mothers. Correlation between extrovert personality type, type B maternal education, economy, maternal age, parity and duration of labor process was analyzed by logistic regression using the backward method. The first step regression analysis was performed by bivariate selection. Variables with $p$ value $\leq 0.250$ were entered in the selection multivariable. The analysis showed that age, parity, economics and education had $p$ value $>0.250$, so they were not included in the multivariable selection.

Table 3 shows the correlation between extrovert personality type and the duration of labor after consideration of external variables (maternal age, parity, economy and education). Type A mothers had 8.2 times higher risk (95\% CI: 3.72-18.4) than type B mothers. Parity and maternal age were not confounder variables in determining correlation between personality type and the duration of labor.

\section{Discussion}

This study found a correlation between extrovert personality types with prolonged second stage of labor. This strong association is marked by relative risk (RR) of 8.2. These results are in line with previous studies conducted.

Table 1. Subject Comparability (Case vs. Control)

\begin{tabular}{|c|c|c|c|c|c|c|}
\hline Variable & Category & $\mathrm{n}=\mathbf{5 2}$ & $\%$ & $n=104$ & $\%$ & p Value \\
\hline \multirow[t]{2}{*}{ Maternal educational background } & Low (elementary, junior high) & 18 & 34.6 & 35 & 33.7 & \multirow[t]{2}{*}{1.000} \\
\hline & High (high school, university) & 34 & 65.4 & 69 & 66.3 & \\
\hline Economy & Low & 40 & 76.9 & 76 & 73.1 & 0.746 \\
\hline Maternal age & Not risky & 46 & 88.5 & 88 & 84.6 & 0.684 \\
\hline \multirow[t]{2}{*}{ Parity } & Risky (1 and > 4) & 24 & 46.2 & 48 & 46.2 & \multirow[t]{2}{*}{1.000} \\
\hline & Not risky & 28 & 53.8 & 56 & 53.8 & \\
\hline
\end{tabular}

Notes:

$\mathrm{n}=$ Number of Sample

Table 2. Correlation between Extrovert Personality Type and Prolonged Second Stage of Labor

\begin{tabular}{lllllllll}
\hline \multirow{2}{*}{ Variable } & Category & \multicolumn{2}{c}{ Case } & \multicolumn{2}{c}{ Control } & \multirow{2}{*}{$\mathbf{p ~ V a l u e ~}$} & OR \\
\cline { 3 - 6 } & & & $\mathbf{n}=\mathbf{5 2}$ & $\%$ & $\mathbf{n}=\mathbf{1 0 4}$ & $\%$ & & \\
\hline \multirow{2}{*}{ Personality type } & Personality type A & 42 & 80.8 & 35 & 33.7 & 0.000 & 8.2 \\
& Personality type B & 10 & 19.2 & 69 & 66.3 & & \\
\hline
\end{tabular}

Notes:

$\mathrm{n}=$ Number of Sample; OR = Odds Ratio 
Table 3. The Correlation between Extrovert Personality Type and Prolonged Second Stage of Labor After Consideration of External Variables

\begin{tabular}{lcccccc}
\hline Variable & $\boldsymbol{\beta}$ & $\mathbf{S E}$ & $\mathbf{p}$ Value & OR & $\frac{95 \% \mathbf{C I}}{\mathrm{L}}$ \\
\hline $\begin{array}{l}\text { Personality type } \\
\begin{array}{l}\text { Type A } \\
\text { Type B (Ref) }\end{array}\end{array}$ & 2.114 & 0.409 & 0.000 & 8.2 & 3.72 & 18.4 \\
\hline
\end{tabular}

Notes:

$\mathrm{SE}=$ Standard Error; $\mathrm{OR}=$ Odds Ratio $\mathrm{CI}=$ Confidence Interval

The results of this study supports previous studies, among others, study by Hassan, ${ }^{11}$ and Allison et al, ${ }^{16}$ who stated that individuals with type A personality were more vulnerable to stress. Thus, it causes physiological changes such as an increase in serotonin in response to emerging stressors. ${ }^{12,17,19}$

Personality type influences biological and psychological responses. In theory, people with type A personality are more prone to stress and anxiety, so the condition affects the labor process. Personality determines a person's reaction to stress. ${ }^{20}$ Stress can lead to an increasing sympathetic muscle tone. This condition also triggers adrenaline release leading to constriction of blood vessels. As a result, it reduces the flow of blood which carries oxygen to the uterine. Eventually, it can lead to failure in the contractions and prolonged labor time. ${ }^{11,16,17}$

Individuals with an introvert personality tend to be more reserved. These people are shy and not very talkactive. They prefer things related to knowledge rather than socializing. Introverts prefer regularity in life and always have an organized plan before doing something. In facing problems, an introvert rarely behaves aggressively. They tend to be calm and able to control their feelings well. Therefore, this kind of person is able to maintain patience. Introverts have much better ability in conflict management than extroverts. ${ }^{14,16}$

According to Eysenck and Wilson in Cale, ${ }^{21}$ people with type A personality tend to develop symptoms of stress, characterized by irritability, aggressiveness, and lack of self-control in expressing displeasure and disappointment. Extroverts are prone to stress. People with this personality type tend to have a competitive nature, aggressive, like challenges, and are prone to emotional outbursts. The competitive nature makes extroverts try hard to prove superiority to others and are achievementoriented. In addition to their competitive nature, this personality type also like challenges, so it is often made under pressure both from themselves and their environment. Aggressive nature makes extroverts impatient and irritable when dealing with people who are against them. Explosive emotion may not be useful in this type of problem. An event may be considered as normal for some people, but for this personality type the same events are major events that can cause serious problems. ${ }^{14,21}$ This is reinforced by the opinion of Potter and Perry, ${ }^{22}$ that personality causes different reactions to the same sources of stress.

According Gunarsa, ${ }^{23}$ a person's personality type affects the psychological response of the mother during childbirth. In this study, the personality type that was assessed as a risk for the incidence of prolonged second stage was extrovert or type A. Some mothers felt that birth was a traumatic experience. For type A personality, childbirth may trigger a greater of stress hormones, such as catecholamines and adrenaline. The release of these hormones can inhibit the release of the hormone oxytocin which is a hormone produced naturally by the body which aims to stimulate uterine contractions. When the hormone oxytocin is inhibited, it will weaken uterine contractions. This resulted in prolonged childbirth process. $^{23}$

Personality type has significant influence on the duration of second stage of labor. It is necessary to provide support and psychological support from family and birth attendants to avoid stress on mothers, especially for extrovert women in order to prevent prolonged labor. A mother's personality type is one of the important factors which affect her psychological condition and labor process. ${ }^{16}$

This study used a case control design because the prevalence of prolonged second stage of labor was rare. The main focus of retrospective investigation was the outcome (prolonged second stage of labor). Then it was traced backward to see the exposure (personality type). Similar study was conducted on the relationship between personality traits and labor pain intensity by Yadollahi et $a l,{ }^{24}$ but study used cross-sectional design. Some biases in this study were controlled. Selection bias was controlled by selecting the case and control groups, which used the same criteria and sampling from the same population. Bias control was conducted by blinding in data collection (personality type). This means that data were gathered by an enumerator who did not know the status of outcomes (duration of labor). This study also involved a control. Control of confounders was conducted by using multivariable analysis. The results showed that the correlation between personality type and duration of labor remained significant when covariates were controlled for. Chance variation was accounted for by using $\mathrm{CI}$ and p value. ${ }^{18}$

The results of this study indicated that there was a significant correlation between extrovert personality type and prolonged second stage of labor with $\mathrm{p}$ value $=0.000$ and $95 \% \mathrm{CI} 3.72$ to 18.4 , $\mathrm{p}$ value $<0.05$ with narrow CI. These results strongly suggest that the relationship found was not due to random variation. The results of this study may reasonably be generalized to all women who give 
birth with the same type in all district hospitals in Yogyakarta.

\section{Conclusion}

Extrovert personality type has a strong correlation with prolonged second stage of labor after controlled by other factors. Type A mothers have a risk 8.2 times higher (95\% CI: 3.7-18.4) for prolonged second stage of labor than type B mothers.

\section{Recommendation}

It is necessary to provide support and psychological support for family and birth attendants to avoid stress among mothers, especially for extrovert women in order to prevent prolonged labor. To expand the domain of study, it is necessary to replicate this study in various multicenter populations.

\section{References}

1. Altman M, Sandström A, Petersson G, Frisell T, Cnattingius S, Stephansso, O. Prolonged second stage of labor is associated with low Apgar score. European Journal of Epidemiology. 2015; 30(11): 1209-15.

2. Li W, Zhang H, Ling Y, Jin S. Effect of prolonged second stage of labor on maternal and neonatal outcomes. Asian Pacific Journal of Tropical Medicine. 2011; 4(5): 409-11

3. American College of Obstetrics and Gynecology. Operative vaginal delivery. Clinical management guidelines for obstetrician-gynecologists. American College of Obstetrics and Gynecology. International Journal Gynaecology \& Obstetric. 2001; 74(1): 69-76.

4. Brown S, Gartland D, Donath S, MacArthur C. Effects of prolonged second stage, method of birth, timing of caesarean section and other obstetric risk factors on postnatal urinary incontinence:an Australian nulliparous cohort study. An International Journal of Obstetrics and Gynaecology. 2011;118(8): 991-1000.

5. Statistics Indonesia, National Population and Family Panning Board, Ministry of Health \& Measure DHS ICF Internasional. Indonesia Demographic and Survey 2012. Jakarta. 2013.

6. Laughon SK, Berghella V, Reddy UM, Sundaram R, Lu Z, Hoffman MK. Neonatal and maternal outcomes with prolonged second stage of labor. Obstetrics and Gynecology Journal. 2014;124 (1):57-67

7. Bleich AT, Alexander JM, McIntire DD, Leveno KJ. An analysis of second-stage labor beyond 3 hours in nulliparous women. American Journal of Perinatology. 2012; 29(9): 71-22.

8. Lee L, Jessica D, Azzam H. Management of spontaneous labour at term in healthy women. Journal of Obstetricians and Gynaecologists of Canada. 2016; 38(9): 843-65.

9. Rahmawati WR, Arifah S, Widiastuti A. Pengaruh pijat punggung terhadap adaptasi nyeri persalinan fase aktif lama kala II dan perdarahan persalinan pada primigravida. Kesmas: National Public Health Journal. 2013; 8(5): 204-9.

10. Boroujeni AA, Roohani A, Hasanimanesh A. The Impact of extroversi on and introversion personality types on EFL learners' writing ability. Theory and Practice in Language Studies Journal. 2015; 5(1): 212-8.

11. Hassan HS. The effect of personality behavior pattern, type A and type B, on myocardial ischemia during daily life. The Iraq Postgraduate Medical Journal. 2007; 6 (4): 289-93.

12. Friedman M, Rosenman RH. Type A behaviour and your heart. New York: Plenum Press; 1996.

13. Kitte F, Kornitzer M, Dramaix M. Evaluation of type A personality. Postgraduate Medical Journal. 1986; 62(730): 781-3.

14. Darshani R. A review of personality types and locus of control as moderators of stress and conflict management. International Journal of Scientific and Research Publications, 2015; 4 (2):1-8.

15. Saryono. Health research instruments. Yogyakarta: Pustaka Pelajar; 2010.

16. Allison S, Stafford J, Anumba B. The effect of stress and anxiety associated with maternal prenatal diagnosis on feto-maternal attachment. BMC Women's Health. 2011; 11(33):1-8

17. Lovallo WR. Stress \& health: biological and psychological interactions. 1st ed. SAGE Publications: London. 1997.

18. Kelsey J, Whittemore AS, Evans AS, Thompson WD. Methods in observational epidemiology. Oxford: Oxford University Press; 1996.

19. Chitrayana C, Feby B, Lauren Y, Rumawas ME, Kidarsa VB. Kepribadian tipe A dan risiko hipertensi pada orang dewasa. Kesmas: National Public Health Journal. 2014; 8(8): 380-5.

20. Bibbey A, Carroll D, Roseboom TJ, Phillips AC, Rooij SR. Personality and physiological reactions to acute psychological stress. International Journal of Psychophysiology. 2013; 90(1): 28-36

21. Cale ME. A quantitative review of the relations between the "Big 3" higher order personality dimensions and antisocial behavior. Journal of Research in Personality. 2006; 40: 250-84

22. Potter PA, Perry AG. Buku ajar fundamental keperawatan: konsep, proses, dan praktik. Alih Bahasa: Komalasari R. Jakarta: EGC; 2005.

23. Gunarsa SD. Psikologi Perawatan. Jakarta: BPK Gunung Mulia; 2008.

24. Yadollahi P, Khormaie F, Makvandi S, Soofi A, Ariashekouh A, Hashemifard T. The relationship between personality traits and labor pain intensity. International Journal of Community Based Nursing and Midwifery. 2013; 1(4): 224-29. 